\title{
Regulation of Gap Junctional Intercellular Communication in Human Keratinocyte Cells
}

\author{
Hi-Son Kahng, Byung-Chul Kim, Sung-Ook Kang, \\ Jung-Joo Hong, Hyung-Jin Jun and Yun-Hoon Choung \\ Department of Otolaryngology, Ajou University School of Medicine, Suwon, Korea
}

\author{
사람 상피세포주(HaCaT)에서의 간극결합 세포 간 신호전달의 조절 \\ 강희선 · 김병철 · 강성욱 · 홍정주 · 전형진 · 정연훈 \\ 아주대학교 의과대학 이비인후과학교실
}

Received July 12, 2010

Revised September 12, 2010

Accepted September 30, 2010

Address for correspondence

Yun-Hoon Choung, DDS, MD, PhD

Department of Otolaryngology,

Ajou University School of Medicine,

San 5 Woncheon-dong,

Yeongtong-gu,

Suwon 443-721, Korea

Tel +82-31-219-5263

Fax +82-31-219-5264

E-mail yhc@ajou.ac.kr
Background and Objectives Unlike the normal skin, cholesteatomas characterized by hyperproliferative keratinocytes exhibits up-regulation of connexins (Cxs) and gap junctional intercellular communication (GJIC). Currently, there are no appropriate clinical methods that can inhibit cholesteatoma progression nor are there available optimal in vitro models of cholesteatomas. The objectives of this study were to identify the regulating materials that control GJIC using human keratinocyte cells ( $\mathrm{HaCaT}$ ) and to get preliminary information about how to inhibit cholesteatoma progression with an aim to make in vitro models.

Materials and Method Acetic acid (AA), $\mathrm{H}_{2} \mathrm{O}_{2}$, dexamethasone, retinoic acid (RA), or green tea extracts-epicatechin (EC) and epigallocatechin gallate (EGCG) were used for this study. After HaCaT cells were cultured with chemicals for 24 hours, cytotoxicity was quantitatively analyzed by cell counting and Neutral-red uptake test. Reverse transcriptase-polymerase chain reaction, Western blot and immunocytochemistry were performed to analyze the change of Cx expression. GJIC was functionally evaluated with scrape-loading dye transfer (SLDT).

Results After the 24-hour culture, $\mathrm{H}_{2} \mathrm{O}_{2}$ or EGCG $(100 \mu \mathrm{M})$ were observed to have interfered with cell growth. In the Western blot, $\mathrm{Cx} 26$ and $\mathrm{Cx} 30$ showed higher up-regulation by EGCG or dexamethasone, but less down-regulation by AA or $\mathrm{H}_{2} \mathrm{O}_{2}$ than the control. In comparison with the control, immunocytochemistry $(\mathrm{Cx} 26, \mathrm{Cx} 43)$ showed less expression and abnormal location of Cxs under AA, $\mathrm{H}_{2} \mathrm{O}_{2}$, or $50 \mu \mathrm{M}$ EGCG than the control, and increased up-regulation or equal expression under $5 \mu \mathrm{M}$ EGCG, EC, RA, or dexamethasone was greater than the control. In SLDT, dye transfer was significantly lower in AA- $\mathrm{H}_{2} \mathrm{O}_{2}$, dexamethasone-, or RA-treated cells than in the control cells. EC showed higher dye transfer than the control cells.

Conclusion The expression of Cxs and GJIC on human HaCaT keratinocytes can be upor down-regulated by chemicals such as AA, $\mathrm{H}_{2} \mathrm{O}_{2}$, dexamethasone, or EC. These results may be useful information in understanding the progression or inhibition mechanisms of cholesteatomas. Korean J Otorhinolaryngol-Head Neck Surg 2010;53:675-85

Key Words Gap junctions · Connexins · Cholesteatoma - Keratinocytes · Intercellular communication.

\footnotetext{
서 론

세포의 성장과 분화, 그리고 조직 및 기관의 정상적인 기

능을 위해서는 종합적인 신호전달체계가 확립되어야 한다. 외부환경의 자극을 감지하는 세포외 신호전달(extracellular communication)체계와 이들 정보를 세포내 핵까지 전
} 
달하고 적절한 핵내반응을 유도하는 세포내 신호전달(intracellular communication)체계, 여러 세포에서 일률적으 로 반응하기 위한 세포 간 신호전달(intercellular communication)체계 등이 적절히 기능하여야 세포의 성장, 분 화, 사멸을 조절할 수 있다.

간극결합은 인접세포 간의 세포 간 신호전달체계의 직접 적인 통로로써 비특이적, 수동적 확산에 의해 물질의 이동 이 이루어지는 곳이다. 일반적으로 이동물질의 크기에 따라 비교적 선택적으로 물질 이동이 이루어지는데 cAMP, inositol-1,4,5-triphosphate(IP3)와 같은 $1,000 \mathrm{Da}$ 이하의 작은 물질이나 무기 이온을 통과시키고, 반면에 단백질이나 핵산의 이동은 못하게 한다. 이러한 작은 정보물질의 이동 에 의해 세포는 상호 정보교환을 하게 되고, 이를 통해 각 기관의 발생 및 발육을 조절하고, 그 정상 기능을 발휘하게 된다. ${ }^{1)}$

간극결합은 다유전자 족인 connexin $(\mathrm{Cx})$ 단백으로 구성 되어 있으며, 지금까지 약 20 여 종류의 isoform이 보고되 고 있다. 이들 $\mathrm{Cx}$ 는 종특이성, 조직특이성 분포의 성격을 가지고 있어서 종에 따라서, 그리고 기관 및 조직에 따라서 그 분포양상이 달라진다. ${ }^{2}$ 그 중 $\mathrm{Cx} 26$ 은 내이, 간, 피부, 점막 등에 많이 분포하고, $\mathrm{Cx} 43$ 은 뇌, 심장, 생식선, 각막, 피부 등에 분포하는 것으로 알려져 있으며, 피부 상피세포 에서는 주로 $\mathrm{Cx} 43,26,30,31,37,45$ 등이 분포하는 것 으로 되어 있다. ${ }^{2)} \mathrm{Cx}$ 단백은 내형질세망에서 생성되어 골지 체에서 6개가 모여 connexon이라는 반통로(hemichan$\mathrm{nel}$ )를 만들고 세포막으로 이동하여 인접세포의 반통로와 만나 완전한 통로, 간극결합을 이루게 된다. 이러한 과정에 서 $\mathrm{Cx}$ 단백이 잘못 만들어지거나 세포막으로의 이동이 이 루어지지 않는다면, 그리고 세포막에 있다 하더라도 간극결 합이 닫혀있는 상태이면 세포 간 신호전달은 장애를 받아서 질환이 발생할 수 있다. ${ }^{3)}$ 그 대표적인 것이 $\mathrm{Cx} 26$ 유전자 변 이에 따른 선천성 난청이다. ${ }^{4)}$ 내이에서의 $\mathrm{Cx} 26$ 의 변이는 내 이내 간극결합을 통한 $\mathrm{K}^{+}$의 순환을 방해하여 정상적인 와 우 전위를 유지하지 못함으로써 청각을 소실하게 된다. 그 외에도 Cx32는 Charcot-Marie-Tooth disease, Cx31은 홍반각피증(erythrokeratodermia variabilis), $\mathrm{Cx} 43$ 은 내장역위증(visceroatrial heterotaxia) 그리고 $\mathrm{Cx} 46$, $\mathrm{Cx} 50$ 은 백내장 등의 질환과 연관이 있다고 보고되고 있 다. ${ }^{4,5)}$ 하지만 사람의 상피성 양성질환과 $\mathrm{Cx}$ 의 관련은 거의 밝혀져 있지 않다.

사람의 정상상피에서의 $\mathrm{Cx}$ 의 발현에 관련된 보고를 보 면, $\mathrm{Cx} 43$ 은 모낭 간 상피세포에 주로 분포하면서 상피내 유 극층과 과립층에서 발현되며 기저층에서는 적게 발현되고,
$\mathrm{Cx} 26$ 은 모낭 간 상피세포에서는 거의 발현되지 않고, 모근 과 피부선 근처의 상피 기저층에서 일부 발현되는 것으로 알려져 있고, 세포성장과 분화에 관여하는 것으로 보고 되 었다. ${ }^{6}$ 아울러 상피 증식의 피부질환인 건선에서는 $\mathrm{Cx} 43$ 이 정상적인 발현을 보이나 $\mathrm{Cx} 26$ 의 발현은 현저한 상승을 보 였다고 하고, 특히 $\mathrm{Cx} 26$ 은 상피의 모든 층에서 발견되고, 상피세포의 세포막뿐만 아니라 세포질에서도 발견된다고 한다. ${ }^{6)}$

중이 진주종은 이비인후과에서 쉽게 볼 수 있는 중이질환 의 흔한 원인으로 정상적으로 외이도에 있어야 할 편평상피 세포가 여러 가지 원인으로 인하여 중이강 내에 위치한 것 으로 상피조직의 과증식, 과분화, 과사멸 및 과각화 현상의 병리학적 특성을 보이는 질환이다. 진주종에 대한 기초연구 로 세포내 신호전달 과정과 사멸에 대해서는 지금까지 많은 연구가 이루어져 왔다. Cytokeratin13/16, involucrin, filaggrin, Ki67, proliferating cell nuclear antigen(PCNA), epidermal growth factor recptor(EGFR), platelet derived growth factor(PDGFR), thrombomodulin, phospholipase C- $\gamma 1$, phosphatidyl-inositol 3'-kinase 등과 같은 세포막 수용체 및 세포내 신호전달 물질과 진주종 상피세포 의 사멸과 관련하여 c-jun, p53, FAS, bcl-2 등이 연구 보고 되었다. ${ }^{7}$ 하지만 아직까지 진주종의 세포 간 신호전달 에 관한 연구보고, 즉 간극 결합 및 세포 간 신호전달에 관 한 연구는 국내외적으로 거의 보고된 바가 없다.

유일하게 사람 진주종 상피 조직에서의 $\mathrm{Cx}$ 의 발현에 관 한 보고에서는 진주종 상피세포에서 $\mathrm{Cx} 43$ 및 $\mathrm{Cx} 26$ 이 촉진 되어 있다고 하였다. ${ }^{8)}$ 이는 진주종의 발생기전에 세포 간 신 호전달체계가 관여하고 있다는 증거이며, 아울러 간극결합 단백 $\mathrm{Cx}$ 의 발현을 억제하면 진주종의 진행을 억제할 수 있 다는 가설을 세울 수 있다. 진주종 상피세포에 대한 in vitro 3차원 모델을 위한 배양실험에서 배양이 용이한 Ha$\mathrm{CaT}$ 세포주를 삼차원 배양하여 그 특성을 비교하였는데, 같은 사람 상피세포의 일종이지만 여러 가지 단백 및 신호 전달물질의 발현특성에 차이를 보이고 있었다고 한다. $\left.{ }^{9}\right)$ 이 실험을 통하여, 상피세포 성장에 중요한 역할을 하는 세포 간 신호전달체계를 활성화 한다면, 즉 $\mathrm{HaCaT}$ 세포주의 $\mathrm{Cx}$ 발현을 증가시키면 진주종 상피세포와 유사하며 좀 더 용이 한 in vitro 모델을 만들 수 있을 것이라는 또 하나의 가설 을 세울 수 있다. 이러한 두 가지 가설하에 $\mathrm{HaCaT}$ 세포주 에서의 간극결합의 발현을 확인하고 임상적으로 적용이 가 능한 여러 가지 물질을 이용하여 간극결합 단백, $\mathrm{Cx}$ 의 발 현을 조절하는 것이 본 연구의 목적이다. 


\section{재료 및 방법}

\section{재 료}

본 연구에서는 $\mathrm{HaCaT}$ 세포주를 사용하였는데, $\mathrm{HaCaT}$ 세포주는 성인 피부에서 형질변환된 '자연 불사화된 비종양 성, 고분화된 상피세포주(spontaneously immortalized non-tumorigenic and highly differentiating keratinocyte cell line)로서, 불멸(>140 passages)의 특성이 있 으나 정상적인 분화를 보이는 세포주이다. 본 연구에서 사 용된 $\mathrm{HaCaT}$ 세포주는 40 60 계대배양된 것을 사용하였다.

\section{방 법}

본 연구는 크게 4단계로 시행되었다. 첫째 단계는 배양된 $\mathrm{HaCaT}$ 세포주에 $\mathrm{Cx}$ 발현 조절물질을 농도별로 첨가하여 24 시간 배양 후 세포독성을 확인하였고, 역전사중합효소반 응을 이용하여 $\mathrm{Cx}$ 단백을 만들기 위한 전사(transcription)의 과정 mRNA 발현을 확인하였다. 이를 통해 실험에 사용할 각 조절물질의 적절 농도를 정하였다. 둘째 단계는 $\mathrm{Cx}$ 단백을 생성하기 위한 전역(translation)의 과정을 확인 하는 실험으로 Western blot을 시행하여 Cx 단백 발현을 비교분석하였다. 셋째 단계는 $\mathrm{Cx}$ 단백의 발현양상 및 세포 내 분포위치를 확인하기 위한 면역세포화학(immunocytochemistry) 염색을 하여 confocal microscope으로 관찰 하였다. 넷째 단계는 $\mathrm{Cx}$ 단백이 이루는 간극결합의 기능적 분석을 위해 scape loading dye transfer(SLDT) ${ }^{10)}$ 를 시 행하여 세포 간 신호전달의 정도를 분석하였다.

\section{세포배양 및 조절물질 처리}

$\mathrm{HaCaT}$ 세포주를 Dulbecco's Modified Eagle's media (Gibco, New York, USA)에 소태아 혈청(fetal bovine serum) 10\%(Gibco, New York, USA), penicillin/streptomycin $1 \mathrm{x}$ (Gibco, New York, USA)를 추가한 배지에서 $37^{\circ} \mathrm{C}, 5 \% \mathrm{CO}_{2}$ 배양기에서 배양하였다. 배양된 세포를 $0.25 \%$ trypsin/EDTA로 분리한 후, $70 \%$ 정도의 세포로 계대배양하였다. 16시간 정도 키운 후, acetic $\operatorname{acid}(\mathrm{AA}) 2$, 4, 6\%(Duksan, Ansan, Korea), dexamethasone 5, 50, $100 \mu \mathrm{g} / \mathrm{mL}$ (Ilsung, Seoul, Korea), $\mathrm{H}_{2} \mathrm{O}_{2}$ 1, 5, $25 \mu \mathrm{M}$ (Duksan, Ansan, Korea), 녹차추출물인 epigallocatechin gallate(EGCG) 5, 50, $100 \mu \mathrm{M}$ (Sigma, Steinheim, Germany)와 epicatechin(EC) 10, 50, $100 \mu \mathrm{g} / \mathrm{mL}$ (Sigma, Steinheim, Germany), 그리고 retinoic acid(RA) $10^{-4}$, $10^{-5}, 10^{-6} \mathrm{M}$ (Sigma, Steinheim, Germany)로 농도별 처 리하였고 이후 24 시간 배양하였다. 대조군으로는 조절물질
을 처리하지 않은 $\mathrm{HaCaT}$ 세포주를 사용하였다.

\section{세포독성검사}

조절 물질에 의한 세포독성으로 세포가 사멸화한다면 당 연히 $\mathrm{Cx}$ 발현이 안될 것이므로 세포독성이 적은 최대농도를 정하기 위해 24 시간 약물 처리 후 200 배 현미경하에서 18 개 의 $1 \times 1 \mathrm{~cm}$ 격자내의 $\mathrm{HaCaT}$ 세포수를 세었다. 3 회 실험을 시행하였으며, one-way ANOVA 통계적 처리를 하였고, 유 의수준은 $p<0.05$ 로 하였으며 통계 프로그램은 $\mathrm{SPSS}^{\circledR}(\mathrm{SPSS}$ Inc., Chicago, IL, USA) 10.0을 사용하였다.

다른 세포독성검사로 앞선 세포수평가 실험 결과를 기초 로 물질의 적절농도를 재설정하여 Neutral red uptake test 를 다시 3 회 시행하였는데, 이는 살아있는 세포에만 색소를 incorporation 시킨 후에 흡광도를 측정하는 정량적 실험 방법이다. 6 가지 약물을 각각의 농도에 맞추어 multiwell plate에 넣어 배양액과 함께 24시간 동안 세포를 배양한 후 bench에서 배양액을 제거한 뒤 0.33\% Neutral Red Solution[N-2889](Sigma, Steinheim, Germany)를 배양액 양의 $10 \%$ 되는 양과 동일하게 첨가하여 3 시간 배양 후 세 포를 빨리 Neutral Red Assay Fixative[N-4270](Sigma, Steinheim, Germany)으로 세척한 후에 시약을 배양 액과 같은 양의 Neutral Red Assay Solubilization Solution[N-4395](Sigma, Steinheim, Germany)로 녹인 후에 $540 \mathrm{~nm}$ 에서 흡광도를 측정하였다.

\section{역전사중합효소반응에 의한 $\mathrm{mRNA}$ 측정}

전체 RNA는 Easy-BLUETM Total RNA Extraction Kit(Intron, Sungnam, Korea)을 이용하여 분리되었다. 얻어진 전체 RNA를 AccuPower RT Premix(Bioneer, Daejun, Korea)를 이용하여 $1 \mu \mathrm{g}$ 의 농도 cDNA로 $42^{\circ} \mathrm{C}$ 에 서 60 분, $95^{\circ} \mathrm{C}$ 에서 5 분간 역전사하였다. 이미 알려진 염기 서열에 따라 oligonucleotide primers를 고안하였다. 각각 의 primer는 다음과 같다.

\begin{tabular}{|c|c|c|}
\hline \multirow[t]{2}{*}{ Cx26 } & $S$ & 5'- tgttttccagagcaaaccgc -3 ' \\
\hline & AS & 5 - ctgggcaatgagttaaactgg -3 \\
\hline \multirow[t]{2}{*}{ Cx30 } & S & 5 - gcagcatctttttccgaatc -3 \\
\hline & AS & $5-$ atgctcctttgtcaagcagt -3 \\
\hline \multirow[t]{2}{*}{ Cx31 } & S & 5 - atggattggaagaagcttcag -3 ' \\
\hline & AS & 5'- ttaaatgggggtcaggctagg -3 \\
\hline \multirow[t]{2}{*}{$\mathrm{Cx} 43$} & S & 5 - taccatgcgaccagtggtgcget -3 ' \\
\hline & AS & 5'- gaattctggttatcatcggggaa -3 ' \\
\hline \multirow[t]{2}{*}{$\beta$-actin } & S & $5-$ tacatggctggggtgttgaa -3 \\
\hline & $A_{s}$ & 5 - aagagaggcatcctcaccct -3 ' \\
\hline
\end{tabular}


효소중합반응(polymerase chain reaction, $\mathrm{PCR}$ )은 Minicycler $^{\mathrm{TM}}$ (MJ research, Waltham, MA, USA)를 사 용하였고 합성된 cDNA를 Taq DNA polymerase(Bioneer)과 각각의 primer로 증폭시켰다. $\mathrm{PCR}$ 과정은 초기 변 성을 $95^{\circ} \mathrm{C}$ 에서 3 분간 실시하고 $95^{\circ} \mathrm{C}$ 에서 30 초, $56^{\circ} \mathrm{C}$ 에서 30 초, $72^{\circ} \mathrm{C}$ 에서 30 초간 총 38 cycle을 실시한 후, 신전 (extension)은 $72^{\circ} \mathrm{C}$ 에서 5 분간 시행하였다. 역전사중합효 소반응 검사는 3 회 시행하였다.

\section{Western blot에 의한 $\mathrm{Cx}$ 단백의 발현}

Western blot은 3 회 시행되었고 실험 방법은 다음과 같 다. 주어진 조건에서 배양된 $\mathrm{HaCaT}$ 세포주에 $1.0 \mathrm{~mL}$ 의 RIPA 완충액(150 mM NaCl, $1 \% \mathrm{NP} 40,0.5 \%$ dooxycholic acid, $0.1 \%$ sodium dodesyl sulfate, and $50 \mathrm{mM}$ Tris-Cl)을 이용하여 단백질을 분리하였다. 분리된 단백질 은 Bio-Rad protein assay(Bio-Rad, Hercules, CA, USA)를 이용하여 양을 측정하였다. 단백질 분리를 위해 sodium dodesyl sulfate(SDS)-polyacrylamide gel electrophoresis(PAGE)를 사용하였으며 분리된 단백질을 polyvinylidine difluoride(PVDF) membrane(Amersham, Arlington Heights, IL. USA)에 옮겨 $4^{\circ} \mathrm{C}$ 에서 하루동안 polyclonal rabbit anti-Cx26 antibody(1:30,000 Zymed Laboratories Inc., San Francisco, USA), monoclonal mouse anti-Cx43 antibody(1:30,000 Zymed Laboratories Inc., San Francisco, USA)를 반응시켰다. 다음 날 membrane을 $0.2 \%$ Tween-20이 포함된 phosphate buffered saline(PBS) 용액으로 세척한 후 peroxidaseconjugated donkey anti-rabbit antibody(Santa Cruz Biotechnology, Santa Cruz, USA)와 anti-mouse IgG horseradish peroxidase linked whole antibody(Amersham, Buckinghamshire, UK)로 각각 반응시켰다. 1 시간 동안 반응시킨 후 enhanced chemiluminescence detection system(ECL, Amersham, Buckinghamshire, $\mathrm{UK})$ 을 이용하여 X-ray film으로 확인하였다.

\section{면역세포화학(Immunocytochemistry) 염색을 통한 $\mathrm{Cx} 26, \mathrm{Cx} 43$ 의 발현분석}

플라스틱 용기에 분주한 $\mathrm{HaCaT}$ 세포에 각각의 주어진 농도로 acetic acid, dexamethasone, EGCG, epicatechin, $\mathrm{H}_{2} \mathrm{O}_{2}$, retinoic acid를 처리하여 24 시간 동안 $37^{\circ} \mathrm{C}$, $5 \% \mathrm{CO}_{2}$ 배양기에서 배양하였다. 배양된 $\mathrm{HaCaT}$ 세포를 $\mathrm{PBS}$ 로 세척한 후 $3 \%$ paraformaldehyde로 20 분간 $4^{\circ} \mathrm{C}$ 에 서 고정시킨다. 고정된 세포를 $\mathrm{PBS}$ 로 $3 \sim 5$ 분간 3 번 세척하
고 $3 \%$ bovine serum albumin(BSA)가 포함된 PBS에서 1 시간 동안 고정(blocking)시킨 후, PBS에 희석된 polyclonal rabbit anti-Cx26 antibody(1:30000, Zymed Laboratories Inc., San Francisco, USA), monoclonal mouse anti-Cx43 antibody(1:30000, Zymed Laboratories Inc., San Francisco, USA)를 24시간 동안 반 응시켰다. $\mathrm{PBS}$ 와 $0.1 \% \mathrm{BSA}$ 가 포함된 $\mathrm{PBS}$ 로 각각 15 분간 세척하고 어두운 곳에서 $3 \% \mathrm{BSA}$ 가 포함된 $\mathrm{PBS}$ 로 희석된 fluorescein-conjugated Affini Pure goat anti-rabbit IgG(H+L)과 CyTM3-conjugated AffiniPure rabbit anti-mouse IgG(H+L)(Jackson ImmunoResearch, West Grove, USA), 4;6-diamidino-2-phenylindole(DAPI)(Sigma, Steinheim, Germany)를 1시간 동안 처리하였다. PBS로 3 번 세척한 후, 슬라이드에 세포를 고 정시키고 confocal microscope(Olympus, FV300, Tokyo, Japan)을 사용하여 Cx26, Cx43의 발현 정도를 분석 하였다.

\section{간극결합 간 신호전달의 기능적 검사}

SLDT 방법으로서 배양된 세포군이 있는 접시에 외과용 절제 칼을 사용하여 칼자국을 낸 대조군과 실험군 각각에 Lucifer yellow $(0.5 \%)$ 용액을 넣어 5 분간 배양시킨 후, PBS로 3 4회 세척한 이후에 형광 현미경(Axiovert 200, Carl Zeiss, Germany)으로 Lucifer yellow의 세포 간 확 산 결과를 200배율로 관찰하며 디지털 카메라(Axiocam, Carl Zeiss, Göttingen, Germany)로 촬영하여 Tiff 그림 파일로 저장하였다. 실험은 3 회 시행되었고, 실험시마다 각 조건의 사진을 5 곳 이상 촬영하였다. Image $\mathrm{J}^{\circledR}($ National Institutes of Health, Bethesda, USA) $1.37 \mathrm{v}$ 를 사용하 여 저장된 그림 파일을 Grayscale로 변환한 뒤 threshold 를 각 그림에서 동일한 정도로 조정하여 세포의 윤곽선을 표시한 뒤에, 이 윤곽선이 중앙선에서 멀리 떨어져 있는 지 점 순서대로 각 그림마다 14 곳씩 지정하여 각 지점과 중앙 선 간의 거리를 inch 단위로 측정하였다. $\mathrm{SPSS}^{\circledR}(\mathrm{SPSS}$ Inc., Chicago, IL, USA) 12.0 을 사용하여 확산 거리의 평균, 표준편차 값을 구하고, 대조군과 실험군 간 확산 거리 에 차이가 없다는 귀무가설에 대해 t-test를 시행하였다.

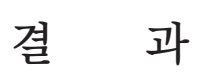

\section{$\mathrm{HaCaT}$ 세포주의 농도별 간극결합 조절물질에 대한 세포독성과 $\mathrm{Cx}$ mRNA의 발현비교}

Acetic acid 0.1, 1, 2\%를 $\mathrm{HaCaT}$ 세포주에 첨가하고 24 
시간 후 200배의 광학 현미경하에서 세포수를 관찰한 결과 와 neutral red uptake 방법에 의한 세포 viability 모두 $1 \%$ 와 $2 \%$ 농도조건에서 세포의 수가 약간 감소하는 경향이 있었으나 통계적으로 유의한 차이는 없었다.

역전사중합효소반응상에서 약물을 처리하지 않은 대조 군에서는 $\mathrm{Cx} 26,43,30,31$ 발현이 관찰되었으나, Acetic acid 1, $2 \%$ 농도에서 Cx31 발현이 거의 관찰되지 않았다 (Fig. 1).

$\mathrm{H}_{2} \mathrm{O}_{2}$ 는 $1,5,25 \mu \mathrm{M}$ 농도의 세포독성 검사에서 24 시간 배양 후 세포의 수가 전체적으로 감소하는 경향이었으나 통
계적으로 의미 있는 경우는 $25 \mu \mathrm{M}$ 이었다. $25 \mu \mathrm{M} \mathrm{H}_{2} \mathrm{O}_{2}$ 의 경우에서는 세포가 사멸하는 경향이 많았다. 역전사 중합 효소반응의 결과에 의하면 모든 농도에서 $\mathrm{Cx} 26,30,43$ $\mathrm{mRNA}$ 는 관찰되었으나, $\mathrm{Cx} 31$ 은 관찰되지 않았다(Fig. 2).

Dexamethasone 1, 10, $100 \mu \mathrm{g} / \mathrm{mL}$ 농도에서 세포독성 검사상 세포의 수 및 Neutral red uptake시 세포생존 정 도가 대조군과 비교하여 큰 변화가 없이 통계적으로 유의한 차이가 없었다. 역전사중합효소반응상에서도 농도에 따른 $\mathrm{Cx} 26,30,31,43$ 의 발현양이 변화가 없었다(Fig. 3).

$\mathrm{EGCG}$ 는 $5,50,100 \mu \mathrm{M}$ 각 농도별로 24 시간 세포 배양
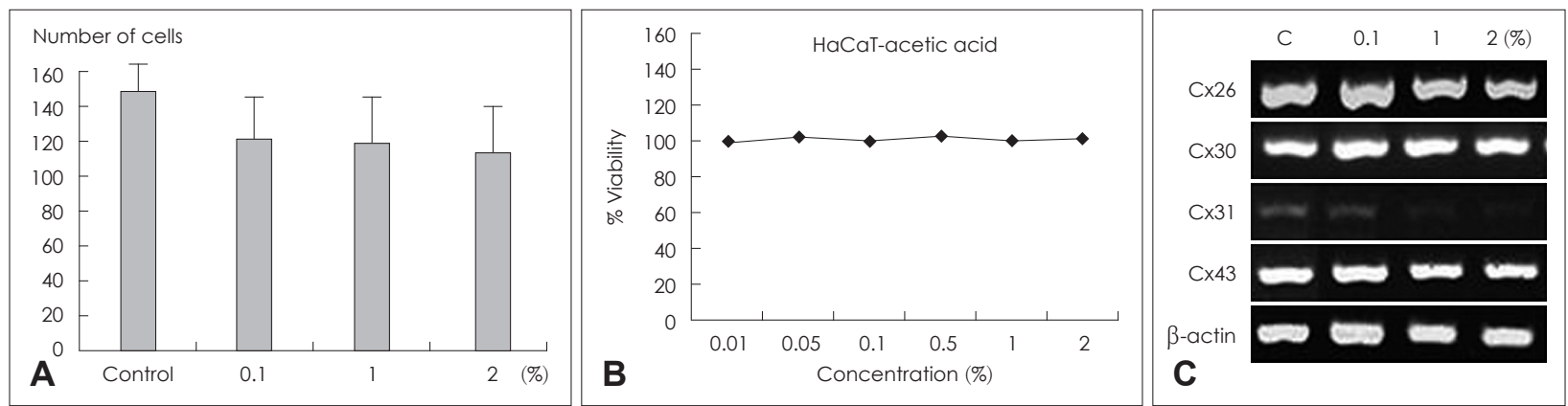

Fig. 1. Effect of acetic acid to the proliferation and Connexin mRNA of HaCaT cells. The proliferation assay (A) and Neutral red uptake test (B) of HaCaT cells do not show significant change of cell number after 24 -hour culture under $0.1,1$ or $2 \%$ acetic acid. RT-PCR shows the expression of $\mathrm{Cx} 26,30,31$, and 43 mRNAs in control cells. However Cx31 mRNAs were nearly not defined under 1 or $2 \%$ acetic acid (C). HaCaT: human keratinocyte cell.
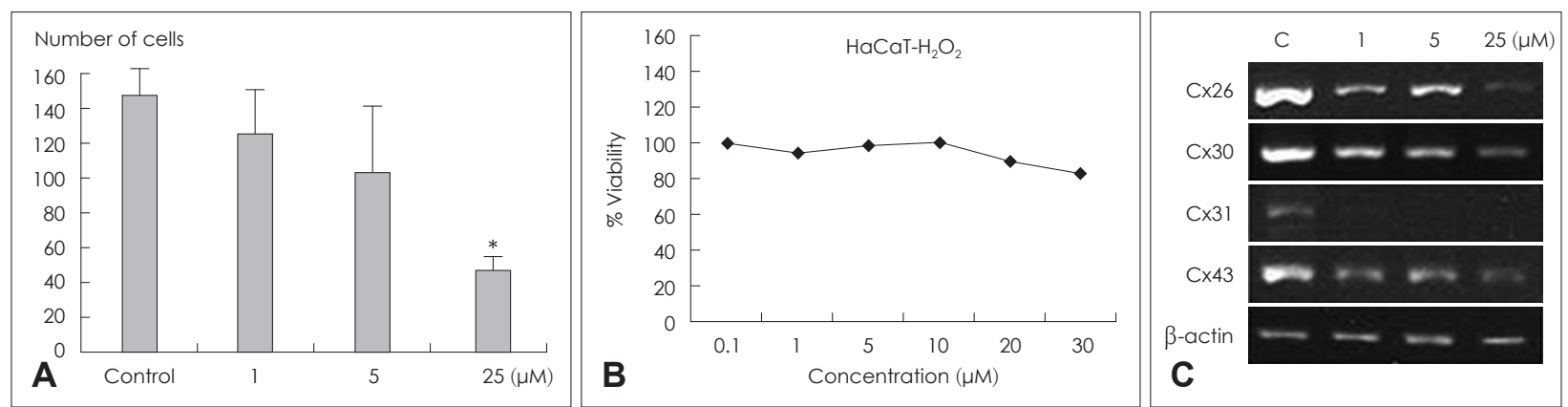

Fig. 2. Effect of $\mathrm{H}_{2} \mathrm{O}_{2}$ to the proliferation and Connexin mRNA of HaCaT cells. The proliferation assay (A) and Neutral red uptake test (B) of $\mathrm{HaCaT}$ cells show significant decrease of cell number after 24-hour culture under $25 \mu \mathrm{M} \mathrm{H}_{2} \mathrm{O}_{2}$, but not under 1 or $5 \mu \mathrm{M} \mathrm{H} \mathrm{O}_{2}$. CX31 mRNA was not expressed in all concentrations of $\mathrm{H}_{2} \mathrm{O}_{2}$ in RT-PCR (C). ${ }^{*} p<0.05$, one-way ANOVA. HaCaT: human keratinocyte cell.
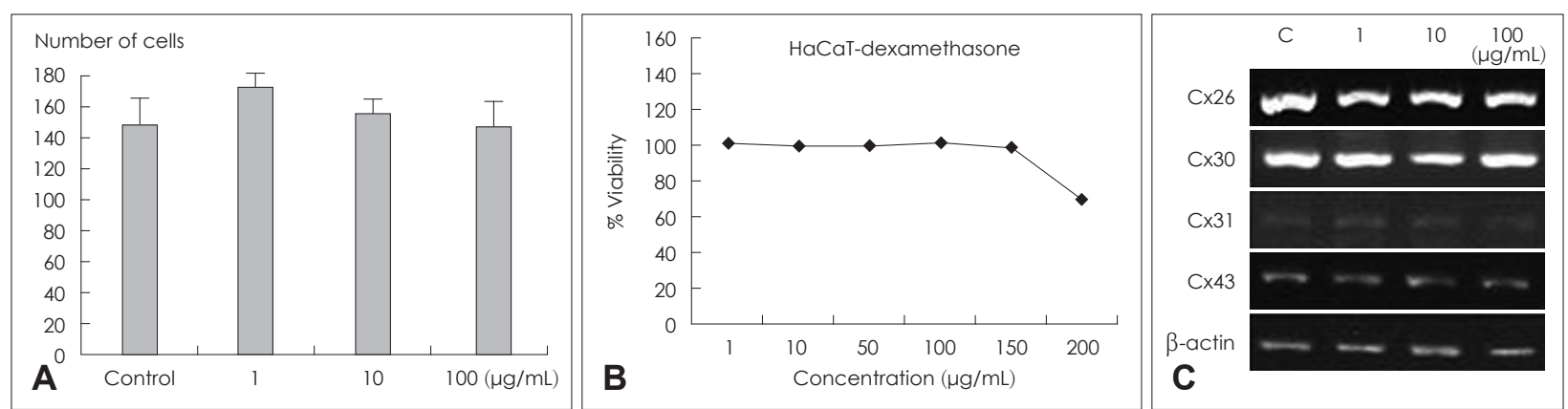

Fig. 3. Effect of dexamethasone to the proliferation and Connexin mRNA of HaCaT cells. The proliferation assay (A) and Neutral red uptake test (B) of HaCaT cells do not show significant change of cell number after 24-hour culture under 1,10 or $100 \mu \mathrm{g} / \mathrm{mL}$ dexamethasone. RT-PCR does not show any different expression of Cx26, 30, 31 and 43 mRNAs compared with control as the concentration of dexamethasone increases (C). HaCaT: human keratinocyte cell. 
한 결과 $5,50 \mu \mathrm{M}$ 에서는 대조군에 비해 큰 차이가 없었으 나, $100 \mu \mathrm{M}$ 에서는 대조군에 비해 통계적으로 유의하게 감 소하였다(Fig. 4A). 역전사중합효소반응 결과에서는 Cx31 의 발현은 모든 농도에서 관찰되지 않았다(Fig. $4 \mathrm{C})$. 그러 나 $\mathrm{EGCG}$ 는 농도에 따라 이중반응(dual reaction)을 보이 는 경향이 있어 세포독성이 있는 $100 \mu \mathrm{M}$ 농도는 제외하고 $5,50 \mu \mathrm{M}$ 농도를 실험농도로 정하였다.

$\mathrm{EC}$ 는 $0.1,1,10 \mu \mathrm{g} / \mathrm{mL}$ 에서 세포독성 검사에서 대조군 과 세포수가 변화가 없었으며, 역전사중합효소반응 결과에
서도 $\mathrm{Cx} 26,30,31,43$ 모두에서 큰 변화가 없었다(Fig. 5). $\mathrm{RA}$ 는 $10^{-4}, 10^{-5}, 10^{-6} \mathrm{M}$ 농도에서 세포독성 검사상 세 포의 수가 대조군과 비교하여 증가한 경우도 있었지만 통계 적인 차이는 없었으며, 역전사중합효소반응 결과에서도 $\mathrm{m}$ $\mathrm{RNA}$ 의 발현이 농도별에 따라 대조군과 차이가 없었다(Fig. 6). 위 결과를 토대로 가능한 세포독성이 없으면서 $\mathrm{Cx} \mathrm{mRNA}$ 의 변화를 보이는 최대 농도를 설정하여 이후 실험을 하였다. Acetic acid 2\%, H2O2 $5 \mu \mathrm{M}$, dexamethasone $100 \mu \mathrm{g} /$ $\mathrm{mL}$, EGCG 5, $50 \mu \mathrm{M}$, EC $50 \mu \mathrm{g} / \mathrm{mL}, \mathrm{RA} 10^{-4} \mathrm{M}$ 을 W-
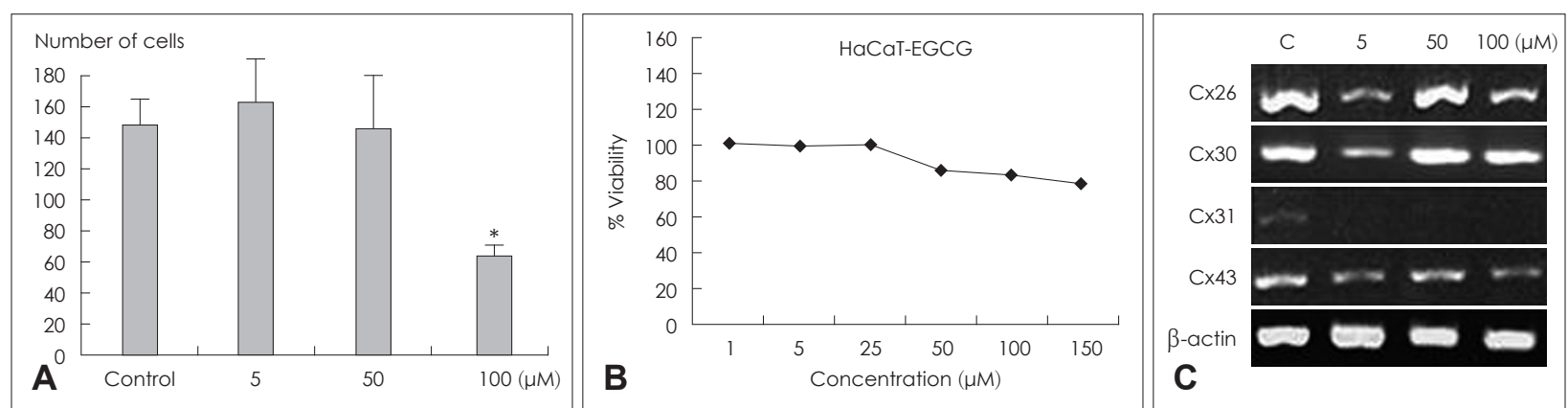

Fig. 4. Effect of epigallocatechin gallate (EGCG) to the proliferation and Connexin mRNA of HaCaT cells. The proliferation assay (A) and Neutral red uptake test (B) of HaCaT cells show significant decrease of cell number after 24-hour culture under $100 \mu \mathrm{M}$ EGCG, but not under 5 or $100 \mu \mathrm{M}$ EGCG. C $\times 31$ mRNA was not expressed in all concentrations of EGCG (C). * $p<0.05$, one-way ANOVA. HaCaT: human keratinocyte cell.
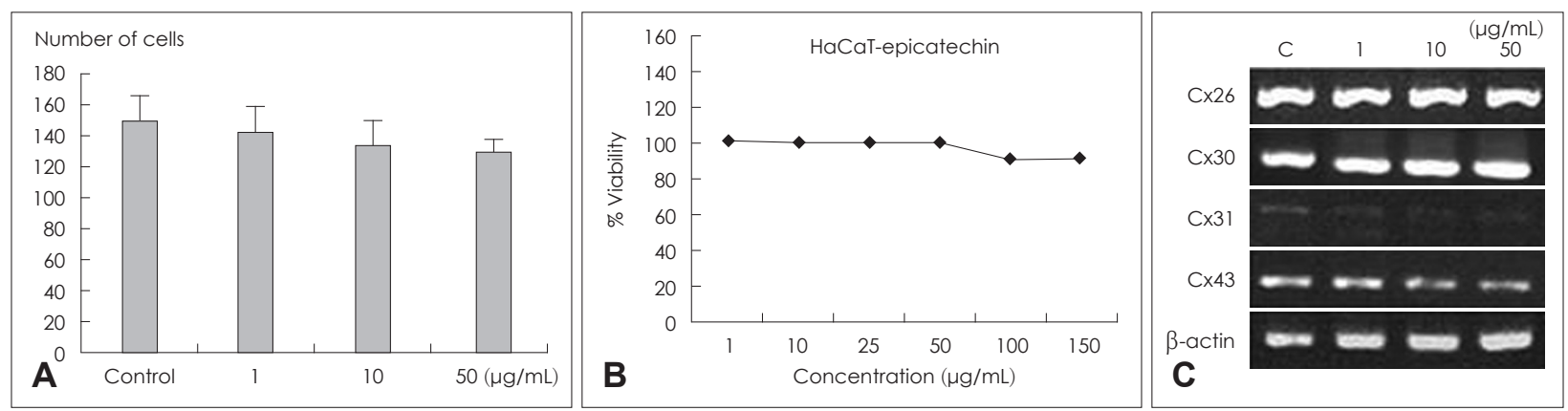

Fig. 5. Effect of epicatechin (EC) to the proliferation and Connexin mRNA of HaCaT cells. The proliferation assay (A) and Neutral red uptake test (B) of HaCaT cells do not show significant change of cell number after 24-hour culture under $0.1,1$, or $10 \mu \mathrm{g} / \mathrm{mL}$ EC. RTPCR does not show any different expression of Cx26, 30, 31, and 43 mRNAs compared with control as the concentration of EC increases (C). HaCaT: human keratinocyte cell.

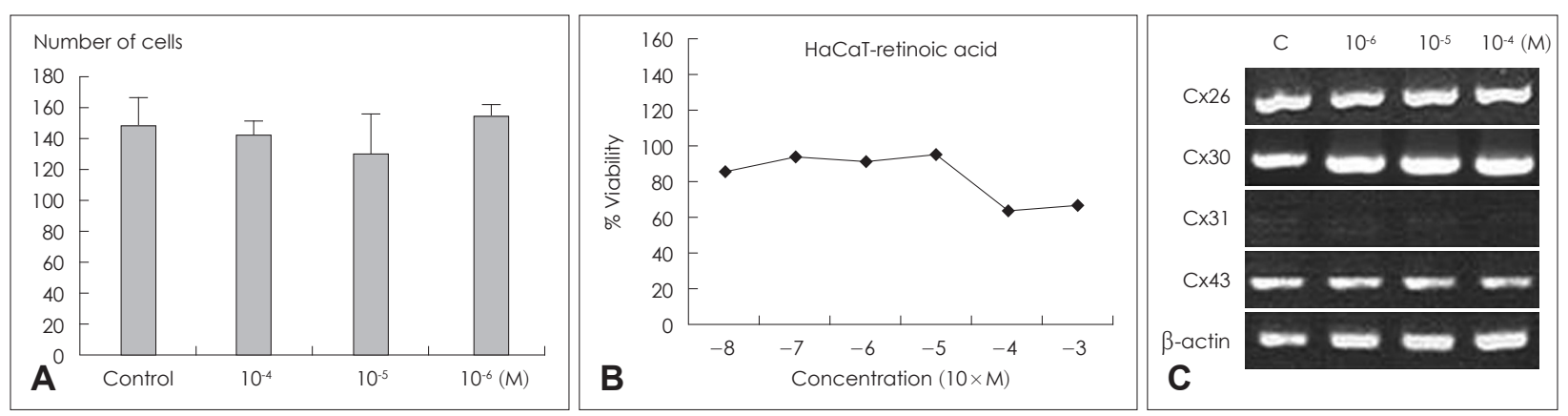

Fig. 6. Effect of retinoic acid (RA) to the proliferation and Connexin mRNA of HaCaT cells. The proliferation assay (A) and Neutral red uptake test $(\mathrm{B})$ of HaCaT cells do not show significant change of cell number after 24-hour culture under $10^{-6}, 10^{-5}$, or $10^{-4} \mathrm{M} \mathrm{RA}$. RTPCR does not show any different expression of Cx26, 30, 31, and 43 mRNAs compared with control as the concentration of RA increases (C). HaCaT: human keratinocyte cell. 
estern blot, 면역세포화학염색에 사용하였다.

\section{Western blot에 의한 $\mathrm{Cx}$ 단백의 발현(Fig. 7)}

$\mathrm{Cx}$ 단백의 생성변화를 확인하기 위하여 $\mathrm{Cx} 26,30,43$ 의 Western blot을 5회 시행하였다. Cx26과 Cx30 단백의 발 현양상은 거의 유사하였는데, acetic acid에서 거의 검출이 되지 않을 정도로 감소하였고, $\mathrm{H}_{2} \mathrm{O}_{2}$ 에서도 $\mathrm{Cx} 26$ 단백발현 이 감소하였다. Dexamethasone은 대조군과 비교하여 감 소(1예), 유사(3예), 증가(1예)의 경우가 모두 있었으나 유사 한 경우가 가장 많았고, $\mathrm{EC}$ 와 RA는 대조군과 유사한 단백 발현 양상을 보였다. $\mathrm{EGCG}$ 는 모두 증가된 발현을 보였는 데, 특히 $50 \mu \mathrm{M}$ 에서 더 증가된 양상을 보였다. $\mathrm{Cx} 43$ 단백 은 처리된 약물에 상관없이 그 발현 정도가 대조군과 거의 유사하였다.

면역세포화학 검사를 통한 $\mathrm{Cx} 26, \mathrm{Cx} 43$ 의 발현 분석(Fig. 8) 대조군 $\mathrm{HaCaT}$ 세포주의 $\mathrm{Cx} 26, \mathrm{Cx} 43$ 은 반점형태로 세 포질과 세포막에 골고루 분포한 양상이었으며, Cx26과 $\mathrm{Cx} 43$ 발현을 융합(merge)시켰을 때 같은 위치에 동시에 발현되는 $\mathrm{Cx}$ 이 많지 않고 각각의 발현색을 유지하는 경향 이었다. Acetic acid를 첨가한 경우에서는 $\mathrm{Cx}$ 발현이 핵주 변에 몰려 응집되는 양상으로 세포막으로의 이동과정(trafficking)에 장애가 있는 것처럼 관찰되었으며, $\mathrm{Cx} 26, \mathrm{Cx} 43$ 융합상에서도 $\mathrm{Cx}$ 의 발현위치가 일치하는 경우가 많아 연두 색으로 많이 관찰되었다. $\mathrm{H}_{2} \mathrm{O}_{2}$ 첨가한 경우에서도 $\mathrm{Cx}$ 발현 이 세포질과 세포막에 퍼져 있기 보다는 핵주변으로 응집되 는 양상이 관찰되었으나, acetic acid처럼 심하지 않았고 융 합 시 일치도 많지 않았다. Dexamethasone, RA, EC 또는 $\mathrm{EGCG} 5 \mu \mathrm{M}$ 을 처리한 경우에서는 대조군과 유사한 형태 의 $\mathrm{Cx}$ 발현이 관찰되었다. 하지만 EGCG $50 \mu \mathrm{M}$ 을 처리한

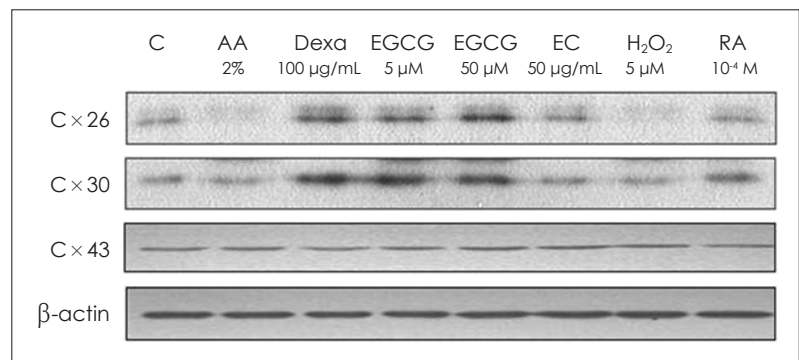

Fig. 7. Western blot analysis of Cx26, 30, and 43. Acetic acid, $\mathrm{H}_{2} \mathrm{O}_{2}$, and dexamethasone show down-regulated expression of $\mathrm{C} \times 26$ and $\mathrm{Cx} 43$ bands compared with control. The expressions in $5 \mu \mathrm{M}$ EGCG, EC, and RA are similar to that of control, but the expression in $50 \mu \mathrm{M}$ EGCG is up-regulated in Western blot. 1: control, 2: $2 \%$ acetic acid, 3: $100 \mu \mathrm{g} / \mathrm{mL}$ dexamethasone, 4: $5 \mu \mathrm{M}$ EGCG, 5: $50 \mu \mathrm{M}$ EGCG, 6: $50 \mu \mathrm{g} / \mathrm{mL}$ EC, $7: 5 \mu \mathrm{M} \mathrm{H}_{2} \mathrm{O}_{2}$, 8: $10^{-4} \mathrm{M}$ retinoic acid. EGCG: epigallocatechin gallate, EC: epicatechin, RA: retinoic acid.
경우에서는 핵주변에 국한된 양상으로 발현이 되었다.

간극결합 세포 간 신호전달에 대한 기능적 검사(Fig. 9)

Acetic acid, $\mathrm{H}_{2} \mathrm{O}_{2}$ 와 dexamethasone은 간극결합간 색 소 이동의 pixel 평균값이 각각 $0.3405,0.3285,0.3562$ 로서 대조군의 값 0.4306 보다 낮았으며 대조군과의 유의한 차이를 보였다 $(p<0.05)$. Epicatechin $(50 \mu \mathrm{g} / \mathrm{mL})$ 은 0.6804 로서 대조군보다 높은 색소이동 수치를 보이며 유의 한 차이를 보여주었다 $(p<0.05)$. 이외에 EGCG $5 \mu \mathrm{M}$, $\mathrm{EGCG} 50 \mu \mathrm{M}, \mathrm{RA}$ 군은 색소 이동 거리 평균이 대조군보 다 증가하였고, 각각 $0.4548,0.4510,0.4343$ 였으나, 유의 한 차이를 보이지는 않았다 $(p>0.05)$.

\section{고 찰}

$\mathrm{Cx}$ 는 거의 모든 조직에서 독성물질 또는 세포성장 및 분 화를 위한 외부신호 자극에 의해서 다양한 형태로 반응을 보이게 된다. $\mathrm{Cx}$ 는 조직 특이성 분포의 특성을 가지고 있어 다양한 기능을 보이게 되는데, 내이 림프액에서의 $\mathrm{K}^{+}$순환, 심장, 근육, 췌장, 신경과 같은 흥분성 세포에서는 전기신호 의 전달, 눈 수정체에서는 영양분 교환 등의 기능을 가지고 있다. 피부 상피세포에서도 다양하고 풍부한 $\mathrm{Cx}$ 이 분포하고 있는데 아직 그 기능을 정확히 파악하고 있지는 않다.

설치류의 피부에서는 적어도 9 종류의 $\mathrm{Cx}$ 이 발생 및 분화 과정에서 발현되고 있다. ${ }^{11)}$ 피부의 기저층에서는 $\mathrm{Cx} 40$, $\mathrm{Cx} 43, \mathrm{Cx} 37$ 이, 유극층에는 $\mathrm{Cx} 43, \mathrm{Cx} 31, \mathrm{Cx} 31.1, \mathrm{Cx} 37$, 그 리고 과립층에서는 $\mathrm{Cx} 31, \mathrm{Cx} 31.1, \mathrm{Cx} 37$ 이 주로 분포한다. 또한 발생과정에서 $\mathrm{Cx}$ 의 발현이 바뀌는 양상을 보일 수 있는 데, 설치류 피부의 성장에서 $\mathrm{Cx} 26, \mathrm{Cx} 37, \mathrm{Cx} 45$ 의 발현은 억제되고, Cx31, Cx31.1, Cx30.3은 촉진된다고 한다. ${ }^{11)}$

사람 피부에서의 $\mathrm{Cx}$ 의 발현은 설치류와 유사하지만 분포 와 기능은 일치하지는 않는다. 사람 피부에서는 기저층에 $\mathrm{Cx} 26$ 이 많고, $\mathrm{Cx} 43$ 이 국소적으로 존재하며, 유극층, 과립 층에는 $\mathrm{Cx} 43, \mathrm{Cx} 31, \mathrm{Cx} 37$ 이 많이 분포하고 있다. 또한 모 낭에는 $\mathrm{Cx} 26, \mathrm{Cx} 43$ 모두가 분포하나 피지선에서는 $\mathrm{Cx} 43$, 한선(eccrine gland)에서는 $\mathrm{Cx} 31, \mathrm{Cx} 26$ 이 많이 분포한 다. ${ }^{12)}$ 한편 피부질환에 대한 $\mathrm{Cx}$ 연구로서 기저층에서 국소 적으로 분포하는 $\mathrm{Cx} 26$ 이 건선, 사마귀, 상처난 상피에서는 전층에서 과발현된다. ${ }^{13)}$ 반면 편평상피세포암, 기저상피세포 암에서는 $\mathrm{Cx} 26, \mathrm{Cx} 43$ 의 발현이 현저히 감소됨으로써 $\mathrm{Cx}$ 가 암유발 억제유전자로서 알려지고 있다. ${ }^{14)}$ 이렇듯 여러 질 환에서 간극결합 단백 $\mathrm{Cx}$ 의 이상발현이 나타남으로써 세포 간 신호전달의 중요성이 부각되고 있다. 


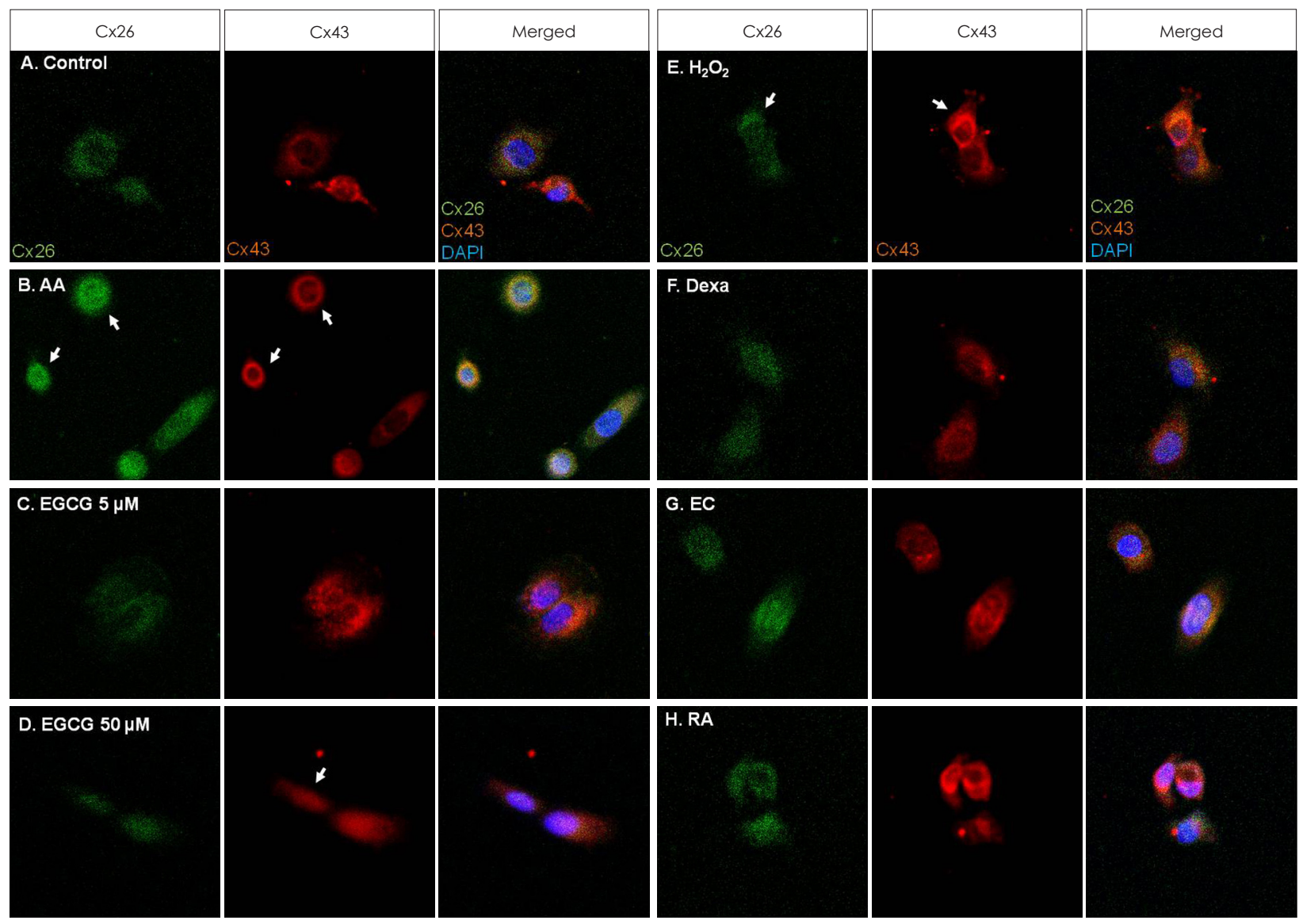

Fig. 8. Immunocytochemical staining of $\mathrm{Cx} 26$ and 43. Immunocytochemistry of HaCaT cells shows abnormal condensed expression (white arrows) of $\mathrm{Cx} 26$ and $\mathrm{Cx} 43$ under acetic acid, $\mathrm{H}_{2} \mathrm{O}_{2}$, or $50 \mu \mathrm{M}$ EGCG. The expression of $\mathrm{Cx} 26$ and $\mathrm{Cx} 43$ under $5 \mu \mathrm{M}$ EGCG, EC, $\mathrm{RA}$, or dexamethasone was similar to those in control cells. A: control, B: $2 \%$ acetic acid, C: $5 \mu \mathrm{M} \mathrm{H}_{2} \mathrm{O}_{2}$, D: $100 \mu \mathrm{g} / \mathrm{mL}$ dexamethasone, E: $5 \mu \mathrm{M}$ EGCG, F: $50 \mu \mathrm{M}$ EGCG, G: $50 \mu \mathrm{g} / \mathrm{mL}$ EC, H: $10^{-4} \mathrm{M}$ retinoic acid. AA: acetic acid, EGCG: epigallocatechin gallate, EC: epicatechin, RA: retinoic acid.

Fig. 9. The results $(A)$ and quantitative analysis (B) of the scrape loading dye transfer (SLDT) method. The maximum distance of lateral spreading of Lucifer yellow dye in SLDT (C). *down-regulation, †upregulation, $p<0.05$. A: control, $\mathrm{B}: 2 \%$ acetic acid, C: $5 \mu \mathrm{M} \mathrm{H}_{2} \mathrm{O}_{2}$, D: 100 $\mu \mathrm{g} / \mathrm{mL}$ dexamethasone, $\mathrm{E}: 5 \mu \mathrm{M}$ EGCG, F: $50 \mu \mathrm{M}$ EGCG, G: $50 \mu \mathrm{g} /$ $\mathrm{mL} E C, \mathrm{H}: 10^{-4} \mathrm{M}$ retinoic acid. AA: acetic acid, EGCG: epigallocatechin gallate, EC: epicatechin, RA: retinoic acid.

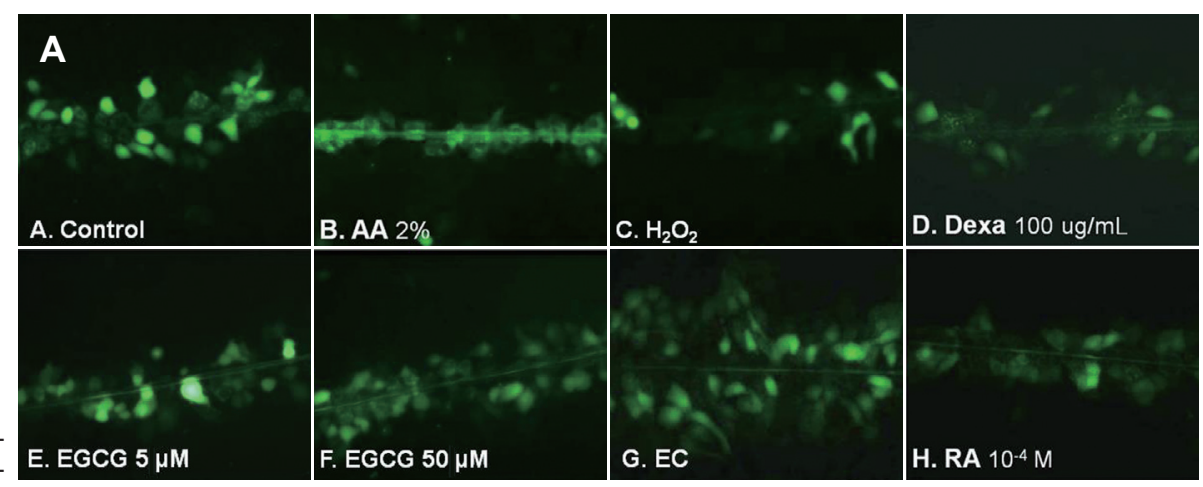

\section{B}

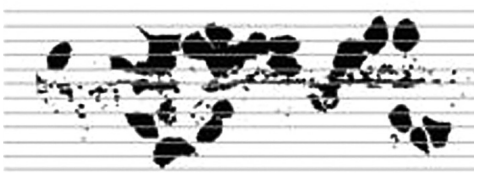

image analysis: Image J by $\mathrm{NIH}$

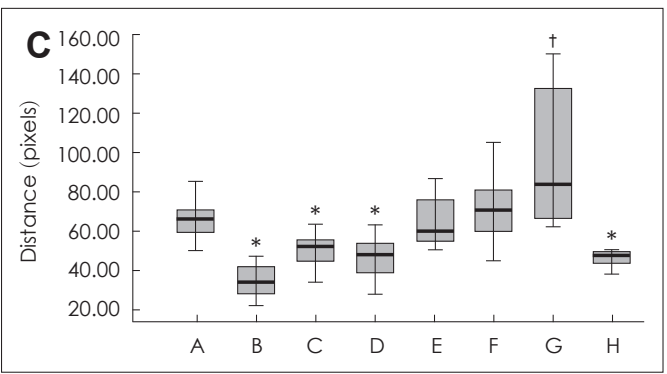


이러한 간극결합 단백 $\mathrm{Cx}$ 의 발현 조절은 세포 간 신호전 달을 조절하는 것으로 결국 세포의 성장과 분화를 조절할 수 있다. 즉, 양성질환을 치료하거나 또는 병의 진행을 억제 할 수 있으며, 발암물질에 의한 암세포화 과정을 억제할 수 있다. 이러한 간극결합 $\mathrm{Cx}$ 의 발현에 영향을 주는 물질로는 여러 가지가 보고되고 있다. 간극결합의 세포 간 신호전달 을 촉진하는 물질로는 vitamin $\mathrm{D}$, ginsenoid $\mathrm{Rb} 2$, epicatechin, ${ }^{15)}$ epigallocatechin-3-gallate, ${ }^{16)}$ retinoic acid, phobol ester, ${ }^{17)}$ epidermal growth factor, lycopene, 고농도 $\mathrm{Ca}^{2+}$ 등이 있다. 간극결합의 세포 간 신호전 달을 억제하는 물질로는 low $\left.\mathrm{Ca}^{2+},{ }^{18}\right) \mathrm{H}_{2} \mathrm{O}_{2}$, steroid, zinc, 12-o-tetradecanoylphorbol-13-acetate(TPA), ${ }^{15)} 1$, 1-bis(p-cholropheny)-2, 2, 2-tricholorethane(DDT) 등이 있다. 이러한 물질들은 실험재료의 대상과 방법들에 의해 그 영향에 차이가 나고 있으며, 실제 보고자에 의해 그 결과도 약간 상이성을 가지고 있다. 더구나 사람 상피세 포의 간극결합 $\mathrm{Cx}$ 의 발현조절을 시도한 경우는 거의 없다.

이과영역에서 흔한 질환인 중이진주종의 발생기전은 아직 까지 정확히 밝혀져 있지 않다. 많은 보고가 세포내 신호전 달에 집중되어 왔고 아직 세포 간 신호전달에 관한 보고는 거의 없다. Choung 등에에 의하면 외이도 상피조직과 비교 할 때 진주종 상피에서 $\mathrm{Cx} 26, \mathrm{Cx} 43$ 이 과발현되고 있으며, 발현위치의 변화가 있음을 보고하면서 진주종 병리기전과 세포 간 신호전달 이상이 관련 있음을 보고하였다. 또한, Raynov (등 ${ }^{9}$ 에 의하면 진주종상피세포의 1 차 배양의 어려 움으로 $\mathrm{HaCaT}$ 세포주의 3차원 배양을 시도하였으나, 진주 종 상피세포의 배양에서는 $\mathrm{HaCaT}$ 세포주 배양보다 cytokeratin 13 과 16 의 발현이 강하는 등 단백발현의 차이가 있 고, 섬유세포와의 접촉배양이 요구되는 등 $\mathrm{HaCaT}$ 세포주를 이용한 진주종 in vitro 모델 제조 시 세포 간 신호전달의 중 요성을 강조한 바 있다.

따라서 본 연구는 상피세포의 간극결합을 조절하면 진주 종과 같은 상피질환의 진행을 억제할 수 있고, $\mathrm{HaCaT}$ 세포 주를 이용한 in vitro 모델도 $\mathrm{Cx}$ 발현 및 세포 간 신호전달 을 조절하면 진주종 성격과 더 유사할 수 있을 것이라는 가 설에서 시작되었다. 한편 사람 상피세포주의 간극결합 조절 에 관한 연구는 향후 상피세포암 발생과정에서의 간극결합 의 역할을 규명하는데 기초자료로 활용될 수 있을 것으로 기대되었다. 따라서 본 연구에서는 가능한 임상적으로 적용 하고 있거나 쉽게 적용할 수 있는 여러 가지 물질을 이용하 여 $\mathrm{Cx}$ 발현을 조절해보고자 하였다.

본 연구에 사용된 $\mathrm{HaCaT}$ 세포주는 성인 피부에서 형질 변환되어 자연 불사화된 비종양성, 고분화된 상피세포주로
서 Fitzgerald 등하의 보고에 의하면 $\mathrm{Cx} 43$ 은 발현이 되지 만 $\mathrm{Cx} 26, \mathrm{Cx} 32$ 는 발현되지 않는다고 한다. 하지만 본 연구 에서는 사람 상피세포에 흔히 분포하는 $\mathrm{Cx} 26,30,31,43$ 을 확인해 본 결과 4 종류 $\mathrm{Cx}$ 모두가 발현이 되고 있었으며, $\mathrm{Cx} 32$ 는 확인하지 못하였다. 본 연구에서 수차례 역전사효 소중합반응, Western blot 및 면역화학염색을 시행한 결과 에 기초하면 Fitzgerald 등 ${ }^{18}$ 의 $\mathrm{HaCaT}$ 세포주에서 $\mathrm{Cx} 26$ 발현이 안된다는 보고는 본 연구의 실험결과와 달랐다.

본 실험에 사용된 간극결합 조절물질은 임상에서 실제 사 용되고 있는 물질로 acetic acid, $\mathrm{H}_{2} \mathrm{O}_{2}$, 스테로이드(Dexamethasone)와 일상에서 쉽게 사용되는 녹차추출물 $\mathrm{EG}$ $\mathrm{CG}, \mathrm{EC}$, 그리고 상피세포 성장에 영향을 주는 것으로 알 려진 RA를 사용하였다. 녹차 추출물은 최근 항발암성 물질 로 많은 연구가 이루어 졌으면) 정상 세포의 증식과 사멸 을 동시에 일으킨다고 보고된 바 있다. ${ }^{19)}$

$\mathrm{Cx}$ 가 기능하기 위해서는 세포질 내에서 생성되어 세포막 에 위치하여야 하는데, 만약 물질에 의한 세포독성이 있다 면 세포사멸에 의해 당연히 $\mathrm{Cx}$ 의 발현이 안될 것이므로, 양 성질환에 적용하기 위하여서는 가능한 세포독성이 적은 농 도를 찾을 필요가 있다. 본 연구에서 $\mathrm{AA}$ 와 $\mathrm{H}_{2} \mathrm{O}_{2}$ 를 사용한 경우에서는 세포의 모양이 전반적으로 섬유세포모양에서 구 형으로 바뀌는 양상이었고, mRNA 발현도 감소하는 경향이 었으며, 농도가 커질수록 변화가 큰 양상이었다. Dexamethasone, $\mathrm{EC}, \mathrm{RA}$ 를 첨가한 경우에는 세포의 모양 및 역 전사효소중합반응상에서 $\mathrm{Cx} \mathrm{mRNA}$ 발현에 큰 변화가 없거 나 약간 증가하는 양상을 보였다. EGCG에서는 농도에 따 라 다른 양상이었는데 $\mathrm{EGCG} 100 \mu \mathrm{M}$ 이상에서는 세포독 성이 나타났으며, $\mathrm{Cx} \mathrm{mRNA}$ 발현은 농도가 $5 \mu \mathrm{M}$ 에서는 저발현, $50 \mu \mathrm{M}$ 에서는 과발현 또는 대조군과 유사한 양상이 었다. 이는 $\mathrm{EGCG}$ 가 $\mathrm{Cx}$ 을 촉진한다는 기존의 보고 ${ }^{16)}$ 와는 약간의 차이를 보이는 결과이다. 결국 세포배양과정에서 세 포독성을 보인 경우는 $\mathrm{H}_{2} \mathrm{O}_{2} 5 \mu \mathrm{M}$, EGCG $100 \mu \mathrm{M}$ 이었다.

Western blot상에서 acetic acid와 $\mathrm{H}_{2} \mathrm{O}_{2}$ 의 경우에서는 확실히 $\mathrm{Cx}$ 단백 생성감소가 분명하게 관찰되어 억제함을 알 수 있었다. 한편 Dexamethasone도 대조군에 비해 $\mathrm{Cx}$ 단백 발현이 약간 감소하는 경향이었으며, $\mathrm{EC}, \mathrm{RA}, \mathrm{EGCG}$ $5 \mu \mathrm{M}$ 에서는 대조군과 거의 차이가 없었다. 반면 EGCG 50 $\mu \mathrm{M}$ 의 경우에서는 $\mathrm{Cx}$ 단백 발현이 증가함을 알 수 있었다. 기존 보고에 의하면 $\mathrm{EGCG}, \mathrm{EC}, \mathrm{RA}$ 모두 $\mathrm{Cx}$ 촉진 물질로 보고된 바 있으나, ${ }^{15,16)}$ 세포에 따라 다른 특성을 보일 수 있 어서인지 본 연구에서는 $\mathrm{EGCG}$ 일부 농도에서만 촉진되었 다. $\mathrm{Cx} 26$ 과 $\mathrm{Cx} 30$ 은 그 단백 발현량이나 발현변화가 거의 일치하는 양상이었으며, 이는 분자량은 약간 다르지만 거의 
기능상으로 일치할 가능성이 있음을 시사하는 결과라 사료 된다.

$\mathrm{Cx}$ 가 세포 간 신호전달 통로로 기능하기 위해서는 내형질 세포망에서 생성된 $\mathrm{Cx}$ 이 골지체에서 6 개 $\mathrm{Cx}$ 이 모여 connexon이라는 반통로를 만들고 이후 세포막으로 이동하는 과 정을 거쳐 인접 반통로와 결합하여 완전한 통로를 형성하게 된다. 이때 connexon을 같은 종류 또는 다른 종류의 $\mathrm{Cx}$ 에 의해 형성되는지에 따라 homotypic 또는 heterotypic이라 하며, 같은 종류의 2 connexon이 통로를 이루는지 여부에 따라 homomeric, heteromeric으로 구분한다. ${ }^{20)}$ 기능적으 로 정확히 규명되지 않았지만 homotypic homomeric 통로 가 다른 isoform으로 구성된 heterotypic heteromeric 통 로보다 기능적으로 우수할 것임은 충분히 예상할 수 있 다. ${ }^{21)}$ 이렇듯 $\mathrm{Cx}$ 단백이 전사, 전역과정을 거쳐 단백이 실제 형성되었다 하더라도 제대로 세포막에 위치하여 통로를 구성 하지 못한다면 세포 간 통로로서 기능할 수 없다.

그래서 본 연구에서는 $\mathrm{Cx} 26, \mathrm{Cx} 43$ 의 $\mathrm{HaCaT}$ 세포주의 분포를 관찰하기 위해 면역세포화학염색 후 $\mathrm{Cx}$ 의 분포를 관찰하였고, SLDT 방법으로 세포 간 염색물질의 이동을 분 석하여 세포 간 신호전달의 기능적 평가를 병행하였다. 조 절물질을 넣지 않은 $\mathrm{HaCaT}$ 대조군에서는 $\mathrm{Cx} 26, \mathrm{Cx} 43$ 의 발현은 세포막뿐만 아니라 세포질 내에서도 반점형태로 관 찰할 수 있었다. 일반적인 세포에서의 간극결합 $\mathrm{Cx}$ 단백이 주로 세포막에서 많이 관찰되는 것과는 달리 $\mathrm{HaCaT}$ 세포 주에서 세포질 내에서도 많이 발현되는 양상으로 보인 것은 in vitro 환경에서 세포증식이 계속되는 상태로 내형질 세망 에서의 $\mathrm{Cx}$ 생성이 활발해서인 것으로 사료된다. 아울러 융 합상에서 $\mathrm{Cx} 26$ 과 $\mathrm{Cx} 43$ 발현이 일치하는 모습은 적었다. 이 는 간극결합 형성 시 세포막에서 비교적 homotypic homomeric 통로를 많이 만듦으로 인해 $\mathrm{Cx} 26$ 과 $\mathrm{Cx} 43$ 발현이 잘 융합되지 않을 것으로 생각된다. 아울러 SLDT에서는 인접세포 3 4개에서의 dye transfer가 관찰되었다. $\mathrm{HaC}-$ $\mathrm{aT}$ 세포주에 acetic acid와 $\mathrm{H}_{2} \mathrm{O}_{2}$ 를 첨가한 경우에서는 $\mathrm{Cx}$ 발현이 핵 주변에 몰려 있는 양상으로 세포질 내 분포형태 를 보여 이동이 잘 되지 않는 양상이었으며 $\mathrm{Cx} 26$ 과 $\mathrm{Cx} 43$
이 주로 동시에 발현되는 것으로 보아 heterotypic heteromeric 통로 형성이 많음을 알 수 있었다. 즉, 세포 간 신호전달을 위한 간극결합 발현이 억제됨을 예상할 수 있 고, 실제 SLDT 기능검사(Fig. 9)에서 세포 간 신호전달이 대조군에 비해 유의하게 감소하였다. Dexamethasone의 경우에서는 비교적 대조군과 유사한 형태의 $\mathrm{Cx}$ 발현을 보 이고 있으나 핵주변 세포질에 더 많이 반점형태로 몰려 있 는 양상으로 관찰되어 있어 이동이 적게 이루어지는 것으로 보여지며, 이는 세포 간 신호전달의 감소를 초래한 것으로 생각된다. $\mathrm{EGCG}$ 는 $5 \mu \mathrm{M}$ 에서는 mRNA가 감소했음에도 불구하고 대조군과 유사한 양상으로 세포질, 세포막에 풍부 한 반점형태의 발현을 보이고 있어 비교적 세포 간 신호전 달이 대조군과 유사하거나 증가할 것으로 보여지며, $50 \mu \mathrm{M}$ 에서는 과발현된 Western blot의 결과에도 불구하고 핵주 변 세포질에 국한된 양상으로 발현이 되고 면역세포화학염 색상 $\mathrm{Cx} 26$ 과 $\mathrm{Cx} 43$ 이 잘 융합되는 양상이어서 오히려 세포 간 신호전달이 감소할 것으로 사료된다. 결과적으로 $\mathrm{Cx}$ 단 백량과 세포내위치 변화(trafficking)는 종합적으로 기능적 역할에 영향을 주는데, Fig. 9와 Tabel 1에 보여지는 것처 럼 EGCG $5 \mu \mathrm{M}, 50 \mu \mathrm{M}$ 모두 대조군과 유사한 세포 간 신 호전달의 결과를 보였다. $\mathrm{EC}$ 와 $\mathrm{RA}$ 는 $\mathrm{Cx}$ 발현이 좀 더 증 가한 양상이었으며, $\mathrm{Cx} 26, \mathrm{Cx} 43$ 융합은 대조군과 유사하 거나 증가하였는데, $\mathrm{SLDT}$ 기능검사에서는 $\mathrm{EC}$ 이 대조군보 다 크게 세포 간 신호전달이 잘 되었고, 반면 RA는 감소하 였다. 결과적으로 SLDT 세포 간 신호전달 기능검사에서 acetic acid, $\mathrm{H}_{2} \mathrm{O}_{2}$, dexamethasone, RA가 세포 간 신호 전달의 기능을 대조군과 비교할 때 유의하게 감소시켰고, $\mathrm{EC}$ 은 유의하게 증가시켰으며, $\mathrm{EGCG}$ 는 큰 차이가 없었다.

결과적으로 본 연구에서 $\mathrm{HaCaT}$ 세포의 $\mathrm{Cx} 26,31,30$, 43 발현 중 여러 화학물질을 통해서 발현조절이 가장 예민 하게 반응하는 $\mathrm{Cx}$ 는 $\mathrm{Cx} 26$ 이었다(Table 1). 이는 곧 $\mathrm{Ha}-$ $\mathrm{CaT}$ 세포주의 간극결합조절에서 $\mathrm{Cx} 26$ 이 중요한 역할을 할 것이라고 추론을 세울 수 있으나, 정확한 기전에 대해서는 추가적인 연구가 필요하리라 사료된다. 아울러 본 연구에서 $\mathrm{Cx}$ 발현을 억제하는 물질로 나타나는 acetic acid, $\mathrm{H}_{2} \mathrm{O}_{2}$,

Table 1. Expression of $\mathrm{Cx} 26$ and intercellular communication in HaCaT cells treated with several chemicals

\begin{tabular}{|c|c|c|c|c|c|c|c|}
\hline & $\mathrm{AA}$ & $\mathrm{H}_{2} \mathrm{O}_{2}$ & Dexa & EGCG $5 \mu \mathrm{M}$ & EGCG $50 \mu \mathrm{M}$ & $\mathrm{EC}$ & RA \\
\hline Cell proliferation & $\downarrow$ & $\downarrow \downarrow$ & $\leftrightarrow$ & $\leftrightarrow$ & $\leftrightarrow$ & $\leftrightarrow$ & $\leftrightarrow$ \\
\hline mRNA & $\leftrightarrow$ & $\downarrow \downarrow$ & $\leftrightarrow$ & $\leftrightarrow$ & $\leftrightarrow$ & $\leftrightarrow$ & $\leftrightarrow$ \\
\hline Protein & $\downarrow \downarrow$ & $\downarrow$ & $\downarrow$ & $\leftrightarrow$ & $\uparrow$ & $\leftrightarrow$ & $\leftrightarrow$ \\
\hline Trafficking & $\downarrow \downarrow$ & $\downarrow$ & $\leftrightarrow$ & $\leftrightarrow \uparrow$ & $\downarrow$ & $\uparrow$ & $\uparrow$ \\
\hline Dye transfer & $\downarrow \downarrow$ & $\downarrow$ & $\downarrow$ & $\leftrightarrow$ & $\leftrightarrow$ & $\uparrow$ & $\downarrow$ \\
\hline
\end{tabular}

$\uparrow$ : up-regulation, $\downarrow$ : down-regulation, $\leftrightarrow$ : no change. AA: acetic acid, Dexa: dexamethasone, EGCG: epigallocatechin gallate, EC: epicatechin, RA: retinoic acid, HaCaT: human keratinocyte cell 
Dexamethasone, RA는 진주종의 항진되어 있는 $\mathrm{Cx}$ 의 발 현8)을 억제시킬 수 있을 것으로 기대되는데, 이는 진주종의 성장을 저해하는 기술로 적용될 수 있음을 시사한다. 하지만, 치료물질로서 바로 적용할 수는 없으며, 진주종의 체외 배양 모델 및 동물모델 실험을 통한 추가적인 검증이 요구된다.

\section{Acknowledgments}

This research was supported by the Korea Research Foundation Grant funded by the Korean Government (MOEHRD, Basic Research Promotion Fund) (KRF-2006-E00081).

\section{REFERENCES}

1) Loewenstein WR. Junctional intercellular communication and the control of growth. Biochem Biophys Acta 1979;560(1):1-65.

2) Richard G. Connexins: a connection with the skin. Exp Dermatol 2000;9(2):77-96.

3) Yamasaki H. Role of disrupted gap junctional intercellular communication in detection and characterization of carcinogens. Mutat Res 1996;365(1-3):91-105.

4) Park HJ, Hahn SH, Chun YM, Park K, Kim HN. Connexin 26 mutations associated with nonsyndromic hearing loss. Laryngoscope 2000;110(9):1535-8.

5) Meyer W, Wehrend A, Schnapper A, Bostedt H. immunohistochemical demonstration of connexin-related epithelization defects in a lamb caused by (erythro)keratodermia variabilis. J Vet Med A Physiol Pathol Clin Med 2005;52(3):153-6.

6) Labarthe MP, Bosco D, Saurat JH, Meda P, Salomon P. Up-regulation of connexin 26 between keratinocytes of psoriatic lesions. J Invest Dermatol 1998;111(1):72-6.

7) Shinoda H, Huang CC. Expressions of c-jun and p53 proteins in human middle ear cholesteatoma: relationship to keratinocyte proliferation, differentiation and programmed cell death. Laryngoscope 1995;105(11):1232-7.

8) Choung YH, Park K, Kang SO, Markov Raynov A, Ho Kim C, Choung PH. Expression of the gap junction proteins connexin 26 and connexin 43 in human middle ear cholesteatoma. Acta Otolaryngol 2006;126(2):138-43.

9) Raynov AM, Choung YH, Park HY, Choi SJ, Park K. Establishment and characterization of an in vitro model for cholesteatoma. Clin Exp Otorhinolaryngol 2008;1(2):86-91.
10) el-Fouly MH, Trosko JE, Chang CC. Scrape-loading and dye transfer. A rapid and simple technique to study gap junctional intercellular communication. Exp Cell Res 1987;168(2):422-30.

11) Butterweck A, Elfgang C, Willecke K, Traub O. Differential expression of the gap junction proteins connexin $45,-43,-40,-31$, and -26 in mouse skin. Eur J Cell Biol 1994;65(1):152-63.

12) Salomon D, Masgrau E, Vischer S, Ullrich S, Dupont E, Sappino p, et al. Topography of mammalian connexins in human skin. J Invest Dermatol 1994;103(2):240-7.

13) Lucke T, Choudhry R, Thom R, Selmer IS, Burden AD, Hodgins MB. Upregulation of connexin 26 is a feature of keratinocyte differentiation in hyperproliferative epidermis, vaginal epithelium, and buccal epithelium. J Invest Dermatol 1999;112(3):354-61.

14) Sawey MJ, Goldschmidt MH, Risek B, Gilula NB, Lo CW. Pertubation in connexin 43 and connexin 26 gap junction expression in mouse skin hyperplasia and neoplasia. Mol Carcinog 1996;17(2): 49-61.

15) Kang KS, Kang BC, Lee BJ, Che JH, Li GX, Trosko JE, et al. Preventive effect of epicatechin and ginsenoside $\mathrm{Rb}(2)$ on the inhibition of gap junctional intercellular communication by TPA and H(2)O(2). Cancer Lett 2000;152(1):97-106.

16) Garbisa S, Sartor L, Biggi S, Salvato B, Benelli R, Albini A. Tumor gelatinase and invasion inhibited by the green tea flavanol epigallocatechin-3-gallate. Cancer 2001;91(4):822-32.

17) Ara C, Massimi M, Devirgiliis Conti L. Retinoic acid modulates gap junctional intercellualr communication in hepatocytes and hepatoma cells. Cell Mol Life Sci 2002;59(10):1758-65.

18) Fitzgerald DJ, Fusenig NE, Boukamp P, Piccoli C, Mesnil M, Yamasaki H. Expression and function of connexin in normal and transformed human keratinocytes in culture. Carcinogenesis 1994; 15(9):1859-65.

19) Chung JH, Han JH, Hwang EJ, Seo JY, Cho KH, Kim KH, et al. Dual mechanisms of green tea extract (EGCG)-induced cell survival in human epidermal keratinocytes. FASEB J 2003;17(13): 1913-5.

20) Stauffer KA. The gap junction proteins $\beta 1$-connexin (connexin-32) and $\beta 2$-connexin (connexin-26) can form heteromeric hemichannels. J Biol Chem 1995;270(12):6768-72.

21) Bevans CG, Kordel M, Rhee SK, Harris AL. Isoform composition of connexin channels determines selectivity among second messengers and uncharged molecules. J Biol Chem 1998;273(5):2808-16. 